PRODUCING TEMPORARINESS, (RE)PRODUCING PRECARIOUSNESS: REGULATION, RIGHTS AND NON-CITIZENSHIP STATUS OF TEMPORARY IMMIGRANT WORKERS / PRODUCIENDO TEMPORALIDAD, (RE)PRODUCIENDO PRECARIEDAD: REGULACIÓN, DERECHOS Y ESTATUTO NO CIUDADANO DE LOS TRABAJADORES INMIGRANTES TEMPORALES

\section{TRYING TO SECURE A FUTURE IN UNCERTAIN CIRCUMSTANCES. THE SOCIAL SECURITY OF TEMPORARY MIGRANT WORKERS IN FINLAND}

\author{
Mika Helander \\ Åbo Akademi University \\ mika.helander@abo.fi \\ Peter Holley \\ University of Helsinki \\ peter.holley@helsinki.fi \\ Heidi Uuttana \\ University of Helsinki \\ heidi.uuttana@gmail.com
}

\section{ASEGURAR EL FUTURO EN CIRCUNSTANCIAS INCIERTAS. LA SEGURIDAD SOCIAL DE LOS TRABAJADORES INMIGRANTES TEMPORALES EN FINLANDIA}

Cómo citar este artículo/Citation: Helander, M.; Holley, P. and Uuttana, H. (2016). "Trying to secure a future in uncertain circumstances. The social security of temporary migrant workers in Finland". Arbor, 192 (777): a286. doi: http://dx.doi. org/10.3989/arbor.2016.777n1002

Received: September 12th, 2013. Accepted: October 31st, 2014.

ABSTRACT: This article deals with temporary migrant workers experiences of social security in Finland, and the question how temporality influences the motivations of migrant workers to find out about their rights in the welfare system. What kinds of experiences do temporary migrants have? Have they met specific problems related to temporariness? The article shows how motivations to find out about the welfare system are linked to the length of stay of the migrant, sector of work, gender of the temporary worker, country of origin of the worker. Finally motivations are in a high degree influenced by objective possibilities of accessing the welfare benefits of the country, for instance related to problems in receiving work permits, residence permits, and the national insurance institution (KELA) insurance cards. The article shows how many temporary workers, especially within seasonal agricultural work, are in Finland solely in order to work, and are not directed towards other aspects of life while in Finland. Temporary migrants learn about the Finnish Social Security System through their own experience, which makes their knowledge dependent on initiation processes at work places. In many cases a private insurance is required from the temporary worker in order to get the visa and many immigrants are not motivated to contribute to a system, which they don't benefit of. Migrants incorporate possibilities provided by the social system. They thus adjust their subjective expectations to the objective conditions. Sometimes this adjustment is done in frustration as benefits are out of reach despite having to contribute to the system financially by paying taxes.

KEYWORDS: Finland's social security; temporary labour migration; motivation; social insurance; time.
Copyright: @ 2016 CSIC. This is an open-access article distributed under the terms of the Creative Commons Attribution-Non Commercial (by-nc) Spain 3.0 License

RESUMEN: Este artículo se centra en las experiencias en materia de seguridad social de los trabajadores migrantes temporales en Finlandia y analiza la influencia de su estatuto temporal en las motivaciones para obtener información sobre sus derechos, así como los problemas específicos derivados de su condición temporal. Esta motivación está determinada por diversos factores como son la duración de su estancia, el sector productivo, el género y el país de origen. Por último, el artículo muestra que las motivaciones están muy influidas por las posibilidades objetivas de acceso a los beneficios sociales del país y sostiene que la presencia de trabajadores inmigrantes temporales, especialmente los insertos en el sector agrario, se restringe al ámbito laboral, encontrado limitaciones de acceso a otras esferas de la vida social. El conocimiento de los trabajadores temporales sobre el sistema finés de seguridad social se adquiere a través de la experiencia, por lo que este está condicionado por las condiciones de la incorporación inicial al mercado de trabajo. Los migrantes adaptan sus expectativas subjetivas a sus condiciones objetivas; un ajuste marcado por la frustración debido a sus dificultades de acceso a beneficios sociales, a pesar de las contribuciones que realizan al sistema a través del pago de impuestos.

PALABRAS CLAVE: Seguridad social finlandesa; migración laboral temporal; seguros sociales; motivación; tiempo y estatuto de residencia. 


\section{INTRODUCTION}

Temporary labour migration has become an attractive resource in several low paid jobs within the agricultural, service and construction sectors. Labour shortages are filled with the entrance of temporary migrant workers. In this new situation different institutional stakeholders have expressed diverse standpoints. For employers - both on a national and a transnational level - the opening up of national labour markets has entailed new possibilities of making profits. Some trade unions have raised concerns over the lowering of working conditions by the use of short-term migrant workers who only spend short periods working in Finland. The role of the state is more ambivalent than that of employers/trade unions. On the one hand labour shortages are problematic for the economy and the temporary stay of labour migrants decreases the need for welfare provisions. On the other hand the same rules and regulations should apply for temporary migrant workers in the labour market, for instance regarding social security, minimum wages and legal protection, and exploitation in any manner should be prohibited. The best-case scenario is a "triple win situation" in which the host country, the sending country, and the temporary labour migrant all benefit from the process (European Migration Network, 2011).

Currently, in the face of the European Monetary Union, in which member states do not retain the ability to devaluate their currencies, a migrant work force becomes a buffer with which fluctuations in conjunctures are handled. Policymakers who promote temporary and circular migration claim that through this particular kind of migration labour shortages will be filled in the host countries, without increasing the costs for providing welfare and integration (European Migration Network, 2011, pp. 9-10).

Almost all work related migration to Finland from third countries can be considered temporary as the residence permits based on employment are time limited and need to be renewed regularly in order to stay in the country (cf. The Finnish Immigration Service). Many different estimates exist, however, about the quantity of the temporary foreign work force in Finland, due to the fact that it is difficult to compile reliable statistics on temporary work related migration and much temporary work is conducted without the need of an employment based residence permit. What is common in the estimates is that the number has increased largely during recent years. In 1990s the yearly number of foreigners coming to work in
Finland according to permit statistics was around 10 000 persons per year. At the change of the millennium the number had doubled (von Hertzen-Oosi et al., 2009, pp. 26-27). The EU enlargement in 2004 and the abolishing of the transition period for free movement for new member state citizens in 2006 have further increased the numbers. It was estimated that in 201031000 posted workers worked in Finland of which 24000 where not included in the taxation register (Hirvonen, 2011, p. 2).

Construction employs the largest numbers of temporary migrant workers. But services, especially cleaning, transportation and seasonal work in agriculture employ also large numbers of temporary workers. In 2013 the number of foreigners registered with a taxation number for work within construction was around 54000 persons. Almost 16000 of these workers have their home municipality abroad (The Finnish Tax authority). Estonians, Russians and Polish workers constitute the biggest nationalities in the register (YLE 22.5.2013). The first two groups constitute the largest groups even in other professions such as seasonal agricultural work and transportation and they are also the largest immigrant groups in Finland (The Ministry of the Interior, 2013). Foreign students constitute a large group within the temporary migrant work force in Finland. Their studies are limited to the time span of the degree program, and they often move back to their home country or further after completing their studies in Finland. Foreign students usually work in order to finance their living in Finland. Between 2010 and 2012 the number of residence permits based on studies in Finland increased from around 4500 to 6500 per year (The Ministry of the Interior, 2011; The Ministry of the Interior 2012; The Ministry of the Interior 2013). In addition to these numbers students from EU member states are not in need of residence permits.

Temporary migration has challenged Finland's universal welfare system, which is characterized by extensive social insurance and social security, whereby welfare benefits are comprehensively available to all people residing permanently within the territory of the nation state.

A triple win hypothesis is presented in relation to temporary and circular migration (European Migration Network, 2011). According to the first win, the host society benefits from this kind of migration. According to the second win the migrant benefits through migration. According to the third win this kind of migration is beneficial also for the country of origin. ${ }^{1}$ In this article we predominantly focus upon the second win 
by exploring advantages (or disadvantages) of temporary labour migration to the migrant. In particular we focus upon temporary migrants' experiences of social security and of working in Finland. We ask questions such as: What kinds of experiences do these migrants have? Have they met specific problems related to their temporariness? How do the migrants look for information and what kinds of opportunities do the migrants have to acquire information?

Our guiding assumption is that insecurity and possible precariousness related to the fragmentation of work life is particularly dominant in the lives of temporary labour migrants. For example, cultural and linguistic challenges together with lack of other Finland specific knowledge may increase experiences of insecurity in the lives of temporary labour migrants. The temporality of work influences the motivation to find out about issues concerning social security, and may create difficulties for the migrant in cases of accidents or other occupational difficulties.

\section{TEMPORARY LABOUR MIGRANTS AND SOCIAL SECURITY}

\section{The issue}

In this article we analyse the ways in which temporality of stay among circular migrants in Finland, from predominantly non-EU countries, influences migrants' attempts and motivations to find out about, and to utilise social insurance (security). We are interested in analysing whether short-term employment or existential ambiguity about one's stay in Finland influences migrants' motivation to become aware about the extensive social security system of the country. Temporality of stay places various administrative and juridical limits and thresholds for being covered by the social insurance. These regulations, together with the particularities of various employment sectors and the gender, age, country of origin and cultural background of the circular migrant are expected to influence individual subjective motivations to find out about social insurance and to utilize the different services provided by public insurance.

Moreover, on the basis of stories told by our respondents, we question whether the Finnish Welfare State corresponds to a universalistic social-democratic welfare model (Esping-Andersen, 1990a, p. 112, Esping-Andersen, 1990b). This model, then, "crowds out the market and, consequently, inculcates an essentially universal solidarity behind the welfare state. All benefit, all are dependent, and all will presumably feel obliged to pay" (Esping-Andersen, 1990a, pp. 112-113;
Esping-Andersen, 1990b). This universalism has often been discussed in relation to the Scandinavian countries especially when it comes to immigration, both in terms of the functionality of universalistic measures as opposed to tailored measures, and in terms of the possibilities for national solidarity and willingness to pay for the welfare system in circumstances of cultural diversity (Brochmann and Hagelund, 2010). Further, there has been considerable debate during recent years as to whether the public sector can afford to maintain a universalistic welfare model, due to economic problems and a problematic balance of resources (Korkman, 2012). Additionally, we question whether universalistic, residence-based social security is in fact a suitable model in an age of increased circular mobility and transnational practices.

There have emerged many pressures against the universalistic model in Finland, and, indeed, some have claimed that Finland never represented the social-democratic model at all (Julkunen, 2001). Immigration to Finland has, nevertheless, been analysed within the frame of the universalistic model (Forsander et al., 2004, pp. 156-181), with the qualifying observation that highly skilled migrants, who have paid for their education abroad, do not have much motivation to pay high income taxes, even if they receive high levels of social security in return.

\section{The frame of the social security system and social in- surance in Finland}

Social policy is intended to secure individuals lives when they find themselves in vulnerable life-situations and/or in need of assistance. In The Problem of Time in Sociology Werner Bergmann writes about Social Policy as a means of de-futurizing the future through securing what is to come. According to Bergmann (1992, p. 91) "the norm of securing the future has achieved the status of a central idea or value in our society, one followed more and more by technology, law, policy and insurance." Social policy thus has an inherently temporal dimension, and it is in most cases considered as a situational aid, which temporarily, with the exception of old age benefits, helps the individual in his or her problematic life situations. It can be understood both as a societal model of creating probability, stability and predictability and a means of insuring against risks.

The Social Security System (SSS) is considered to be central to the field of social policy. Social security consists of measures that attempt to secure the income and welfare of individuals who are facing social 
risks. In particular, it protects the population in the event of illness, unemployment, old age or the death of the guardian, as well as providing healthcare and aid to families with children. The features of the Finnish Social Security System include social insurance and social aid (welfare), along with welfare services and social assistance (Facta 2005). Social insurance typically includes at least the following elements: an invalidity pension; old age pensions; unemployment benefits; family allowances, such as maternity benefits and child allowance; accident and occupational disease insurances, which compensate invalidity and accidents due to work; sickness allowances; and housing allowances.

The Finnish social insurance system is further divided into two parts. The first part is residence-based, which is provided partially by the Social Insurance Institution of Finland - KELA, and partially by municipalities. The second part is employment-based insurances that are provided by semi-public insurance companies. These include work related pensions and trade union administered unemployment funds. Finland thus represents a blend form of social policy regime (cf. Esping Andersen 1990a; Esping Andersen, $1990 b)$, but it is predominantly universalistic in its emphasis on the residence-based social insurance, which is within the reach for all who permanently reside in the country, regardless of their occupational status. But as we outline in the following this issue is particularly pertinent for international migrants whose stay in Finland is often temporary.

The rules and regulations concerning permanent stay are complicated, with several different valid acts and decrees. But, in order to have residence based social insurance as a third country national residing in Finland, one often has to fulfil the condition regarding previous employment in the country as employment is a key criteria for getting longer term permits and becoming registered in a municipality. ${ }^{2}$ The law on one's home municipality (Laws and Statutes of Finland) regulates the conditions under which a person becomes resident in a municipality, and thus entitled to local welfare measures offered by the municipality. The conditions regarding foreigners from outside of EU state that they must have a residence permit of at least one year and that their entire situation is to be taken into consideration. In the entire situation a valid work contract or studies of at least two years are important prerequisites. Another qualification is that one has been living temporarily without breaks at least one year in a municipality. But according to paragraph 2 (Laws and Statutes of Finland), the local registration office has the right to implement the law in a way that if one is considered to live in two countries and for instance ones family is in the home country, the right to register a home municipality might be prohibited. Those who eventually are considered to live permanently in Finland receive benefits.

KELA - Finland's Social Insurance Institution - makes an assessment if a person is eligible for social security in Finland. According to KELA "Persons moving to Finland are considered to be resident in Finland immediately upon arrival provided that their purpose is to make a permanent home in Finland" (KELA 2010). KELA might, however, consider a person resident in one of Finland's municipalities as not eligible for social insurance according to the Application of residence based social security legislation (Laws and Statutes of Finland). Consequently the rules are fuzzy and complicated, and include detailed regulations that make it difficult for clients to become aware of their rights. There is also an inherent risk of bureaucratic arbitrariness in such complicated regulation and administration.

Temporality of stay has many implications regarding the rights that migrants have. For instance, the length of stay in the country circumscribes political rights, such as voting and campaigning in municipal elections. In Denmark, for instance, temporal aspects have been crucial accessing social rights (Jønsson and Petersen, 2010, pp. 152-157). The same is valid in Finland. For international migrants who often stay in Finland on a temporary basis and who have increasingly moved in order to work, the universalistic welfare system does not function accordingly. Firstly, a migrant's length of stay does perhaps not entitle him/her to residencebased social security. Secondly, if the immigrant is not employed (s)he does not become a permanent resident in a municipality. Thirdly, the migrant who is employed and earns his/ her living through work does not often make extensive use of residence-based social insurance. Often migrants do not stay in Finland long enough to qualify for access to unemployment benefits in case of unemployment. An earnings related pension is a future benefit, which is often only available to the migrant after a long period, as many labour migrants are relatively young people. The migrant is often not entitled to bring his or her family to Finland (if (s)he is from outside the EU), and thus family related social benefits are not valid even if (s)he is registered as a resident in a municipality. Accidental and occupational illness insurance, with compensated invalidity and accidents due to work, is normally available for the tem- 
porary migrant as such insurances are compulsory for the employer in order to protect its workforce. This social security measure is very important, but becomes relevant only in extraordinary situations. Sickness allowance is available for all those migrants who have access to KELA insurance. This lacking functionality is a particular problem in cases where migration is circular and when the migrant's stay is permanently temporary (cf. Rasmussen and Håpnes, 2012). In these cases several years of a migrant's life is perhaps not covered by social security and insurance.

Amongst the existing social policy measures many are oriented to guaranteeing the reproduction, and supply of the work force. These include, for example, public childcare arrangements that facilitate women's participation in working life. In the case of temporary migrants these measures are, however, not relevant, due to the fact that such migrants do not usually bring their families along with them to the destination country. The same situation is applicable with regard to free public education. Some measures are related to situations whereby a person does not have the possibility to earn a living, as in the case of income support. However, for temporary migrants who reside in the country to work this is not pertinent except for cases in which the migrant suffers an accident at work or the sudden loss of employment and (s)he is resident in a municipality.

An important stage in the entrance to the Finnish welfare system is the moment when the person is permitted to reside in Finland permanently (or is granted a residence permit longer than one year), and is covered by the residence-based social security. This can be considered as attaining partial citizenship, which includes social rights but does not endow the political rights granted by conventional citizenship. It is, however, this partial citizenship, with its right to welfare benefits that is crucial to most immigrants. Full citizenship, which provides political rights, is not utilized to its full extent, but many immigrants values social citizenship in terms of the KELA insurance card. On the other hand conventional citizenship is the only form of citizenship that protects against the threat of deportation (cf. Brochmann and Hagelund, 2010, p. 264). Temporary migrants lack both partial and full citizenship and a substantial number of migrants have "increasingly limited access to traditional rights and entitlements" (Piper, 2010, p. 108).

Different categories of immigration status have a great influence on the degree to which one is included in the social insurance system. Depending on the migrant's country of origin (EU or not), their reason for staying in Finland, their length of stay, etcetera, different formal rules apply to the social security coverage of the immigrant. For instance many immigrants come as students to Finland, but need to work during their stay due to economical reasons. In these cases the upgrade from student visa to work visa would improve the possibilities of getting social insurance from KELA. This is, however, for the most part not possible or it is connected with bureaucratic problems. Moreover, educational institutions provide student health care, which is highly subsidised and available for exchange students. This represents a kind of semi-public health insurance, comparable to the work related health services, which the employer stands for in Finland.

Arguments for restricting migrant access to welfare benefits have been presented as a way of avoiding "welfare shopping" and as way of discouraging those labelled "social bums" (Comfort refugee in Denmark and Welfare tourism in Norway) from entering the country. An argument has been made that, when large differences in material welfare exist between countries of emigration and immigration, there is an incentive to migrate in order to access welfare benefits. Alternately another argument claims that without benefits migrant labour may be kept as a temporary workforce; a buffer, which leaves when there is economic downturn and employment opportunities worsen (cf. European Migration Network 2011). This is a highly opportunistic return of the guest worker policy (Gastarbeiter) in the current historical time, where devaluations are impossible as an economic policy measure, due to the EMU common currency. ${ }^{3}$ In such circumstances the state is able to meet fluctuations in the demand of work force with the aid of temporary migrant workers. They are simultaneously not entitled to social security, which would result in costs to the welfare system. Temporary immigrants contribute to the system by working and paying taxes, but at the same time they are not entitled to benefits due to temporary stay in the country. In an economic sense the encouraging of temporary migration in particular is favourable to the welfare state, as the state needs workers to fund the system, but less people who need welfare provisions (European Migration Network, 2011). ${ }^{4}$

\section{Theoretical assumptions and hypotheses}

How does temporality relate to motivation in a temporary migration context? Few studies have investigated this question in this particular context. It is, however, a relevant question since temporariness has a big impact many aspects on an individual's life. 
It may therefore impact the individual's motivation to look for information about and form an attachment to the host country.

Hersch (2011) claims that awareness of temporality influences our behaviour in ways we perceive the world and in actions we take. Being aware of the temporary nature of ones time in a country may therefore influence an individual's actions when it comes to developing social networks, looking for information or the willingness to form an attachment to the host country. According to a Yijälä et al. (2009, p. 155), the temporary nature of migrants' employment has an impact on their motivation to form an attachment to Finland. The authors also claim that their orientation towards the future differs from the immigrants that come to Finland permanently. Migrants staying for a limited period of time were expected to relate to Finland as an interesting environment, integrating into their host society about as much as a tourist. In short, temporary employees are not expected to form an attachment to Finland but to rather integrate quickly and disengage promptly when their employment contracts end.

How then does awareness of temporality relate to motivation? Hersch (2011) states that people are not only influenced by their past but also by their anticipations of the future. He argues that motivational theories within psychology often explain motivation by past or present pushing factors. This means factors in the individuals past or present that steers a person's behaviour in a certain direction. Many studies, however, discuss motivation in light of the future time perspective where motivation is rather seen as something that is influenced by pulling factors (Hersch, 2011, pp. 96-100). Thus, people's imagination and anticipation of the future impacts their behaviour in certain ways. Hersch concludes that we must have a comprehensive view on human motivation that does not solely restrict itself to past-driven factors but also considers future anticipations as relevant determinants of human actions (Hersch, 2011, pp. 99-103). A concrete example of pulling factors in the current study could be the awareness of the temporary nature of ones' stay, which subsequently impacts the individual's behaviour depending on his or her imagination and anticipation. White and Ryan claim that to a great extent social networks may in fact influence the duration of an immigrants stay (White and Ryan, 2008, p. 1468 y p. 1474) The causality may also work the other way around. Namely, the duration of the stay may also influence the extent to which a person is motivated to develop social networks.
Individuals have different reasons and motivations for applying to work abroad, and these may significantly influence how the individual adjusts to his/her new working and domestic environments. In order to develop a comprehensive picture of adaptation, we need to further understand the migrating individual's motivations to emigrate. Tartakovsky and Schwartz (2001) considered three categories of motivations to emigrate: (1) preservation motives, which include the need for physical, social and psychological security; (2) self-development motives, which reflect the importance of personal growth in knowledge and skills; and (3) material motives, which refer to the striving for financial wellbeing (Tartakovsky and Schwartz, 2001). Taking such personal aspirations into consideration may, for example, help to explain why some individuals are more likely than others to work until the end of their contracts abroad (Ward, Bochner and Furnham, 2001, p. 183). For many temporary and circular migrants all of these motivational categories are valid.

In addition to motivations, individual expectations regarding future work and living conditions may have an important effect on adjustment. Bakker and Janowicz-Panjaitan (2009, p. 129) argue that individuals working in temporary organizations focus less on the future and more on the present. Miles (1964, pp. 457459) also claims that people living in temporary settings tend to have a vague future-oriented time perspective: they may neglect the past, ignore future anticipations and rather live in the psychological present. Therefore, Bakker and Janowicz-Panjaitan (2009, p. 129) note, focusing on the present subsequently leads to a deepening of present experiences rather than the succession of events. Being aware of the temporary nature of one's circumstances may, according to Miles (1964, pp. 457-459), in certain situations lead to a boost in motivation and have an energizing effect on the individual. Thus, a narrowed time perspective may lead to greater involvement in the current context and less consideration of a future that stretch beyond the current temporary situation. On the basis of such earlier research, we might expect our respondents to be motivated to gain experience and look for information that would help them achieve their immediate goals (i.e. saving money, gathering experience, etc.) and benefit them during the time of their stay in Finland.

In their study of Polish temporary migration, White and Ryan (2008, p. 1481) found that young people in particular lack valuable social networks, which subsequently may lead to a feeling of helplessness and missing future prospects. They state that people who would 
go abroad for longer than a summer holiday needed a stronger safety net and a more detailed plan. Additionally, White and Ryan (2008) also found that the plans of temporary migrants often change over time: a trip that was supposed to last for only one season may be prolonged due to other interests in the host country, such as language-learning. The study examining the linkages between networks and time-related aspects of migration suggested that formal networks are often hard to sustain during a temporary stay (White and Ryan, 2008, p. 1498). However, White and Ryan (2008, p. 1498) found that some migrants considered the shifting quality of networks liberating. Therefore we might surmise that informal networks may become more important during temporary settings. Connections and relationships may thus influence a broad aspect of a migrant's life such as providing accommodation, jobs, information and emotional support (Boyd, 1989, p. 651). This is also visible in the current data as many of our informants state that they gain information from friends and acquaintances. The temporary nature of their stay may thus influence the kind of social networks the migrant is motivated to develop. The situation of temporary labour migrants is, however, not predominantly explainable by social networks. Interests play a very crucial part when trying to understand the motivations and actions of temporary migrants.

Following the work of Richard Sennett, Rasmussen and Håpnes (2012, p. 8) observe that:

\footnotetext{
"The balance between efforts and rewards will vary depending upon whether the employment relation is a long-term or a short term market transaction. When workers are being asked for extra effort and to suppress their personal needs for the good of the company, this makes sense in a long-term relationship where rewards may follow later. Delayed gratification, however, presupposes a long-term relationship where loyalty and effort are rewarded. In a short-term relationship, it is not possible to work for delayed gratification and it makes no sense to be loyal to an employer who only offers temporary employment [Sennett 1998]."
}

Social insurance, when related to high taxation and lower wages, is a feature of delayed gratification. Correspondingly temporary migrant workers can be expected not to be motivated by an insurance which will pay off when the person is retired. The motivation to work in a foreign country on a temporary basis is based predominantly on money. It is important to earn as much as possible as fast as possible. But the issue becomes somewhat more problematic when the foreign worker earns a smaller salary than the fellow native worker, who gets paid according to the collective agreement. The wage may be a lot larger than it would be back home, but is not as high as the normal (minimum) wage in the country where the work is done. In such cases the temporary migrant worker is in a lose-lose situation, where (s)he is not entitled to the delayed gratification of social insurance and is not entitled to the same wage level as a fellow native worker. In the Helsinki Region wage levels have been influenced by the increase in foreign workforce, especially in low skilled occupations such as cleaning (Hyvinvointikatsaus 4/2012).

This research is thus an attempt to do temporally sensitive sociology, where different temporal aspects become valid, such as: Biographical time, time in work organization, rhythm in work, time in life organization, future time, inner time (stream of thought), past time, strategic time (in-order-to and because motives), and finally historical time (the current epoch).

This classification functions as a grammar for understanding temporal aspects in the analysis of the speech produced by our informants. With the aid of such a grammar we make interpretations in terms of time conceptions, focusing upon several different kinds of temporality. These include length conceptualizations (life-span, work contract length, ongoing flow of time in work), intensity conceptualizations (time pressure, leisure, busyness, instantaneousness), historical and biographical conceptualizations (past, present, future, before, now, after), existential, pragmatic and attitudinal conceptualizations (wishing, waiting, expecting, immediacy, wish fulfilment, utopia), and so forth.

Different temporal conceptions dominate in professions. For instance, agricultural work has traditionally involved a cyclical time conception, with periods of planting, watering and cultivating, harvesting, et cetera, that reoccur cyclically (cf. Frykman and Löfgren, 1979). In academic life the work ethos has been characterised by linearity, evidenced by the ideas of development and enlightenment. Project organisation enhances this time conceptualisation by combining merits and carrier advancement with temporally clearly demarcated project boundaries. In blue-collar work the time conceptualisations have usually been dominated by the everyday pace of life - its routine (cf. Sennett, 1998). Among immigrants the time conceptualisation involves often-momentous aspects of life such as before and after migration, as well as moments of gaining the residence permit and instantaneousness when long-term life projects become difficult due to the temporary time perspective of stay. 


\section{Data and definitions}

We define temporary migrants broadly as consisting of several aspects of temporality. Thus our definition differs somewhat from previous discussions of temporal migration. European Migration Network for instance defines temporary migration in its report by putting emphasis on the intentionality of the migrant. They define temporary migration as the following: "Migration for a specific motivation and/or purpose with the intention that, afterwards, there will be a return to country of origin or onward movement" (European Migration Network, 2011, p. 12). Emphasising intentionality is, however, problematic when the information about for instance formal regulations is insufficient, and when the future due to many conditions is open-ended. In our view temporality follows on the one hand from subjective experiences and considerations, and on the other from objective, regulated temporality. The subjective temporality is based on the indeterminacy of migrant existence, where the question "should I stay or should I go" arises even after long periods of stay abroad. The objective temporality consists of the status of residence, the character of the employment relation, temporality due to the sector of work or the contents of the job itself (Helander and Saksela-Bergholm, 2012, p. 30; Helander, Alho and Saksela-Bergholm, 2011, pp. 136-137). According to a working definition temporary migration in Finland means "minimum and maximum duration [--] from three months to two years" (European Migration Network, 2011, p. 14).

Our data consists of seventy-seven semi-structured qualitative interviews. Informants represent predominantly three different professional categories, i.e. bus drivers, cleaners and seasonal workers in agriculture (berry-pickers along with vegetable-pickers and packers). The sample consists of twenty-eight seasonal agricultural workers, twelve cleaners and nine bus drivers. In addition to these our sample includes one research assistant, four construction workers, one kitchen assistant, three persons who work in tourism, and seven unemployed persons. The remainder of our informants were farmers, entrepreneurs, foremen, shop stewards, and state officials. In this article we have concentrated mainly upon the two largest employee categories: seasonal agricultural workers and cleaners. Seasonal berry-pickers have been the largest category of temporary immigrant workers in Finland during the recent years (European Migration Network 2011 , p. 36). Most of our interviews were conducted in the Helsinki region, but the interviews with season- al workers were conducted in the province of Southern Savo in the surroundings of the town Mikkeli. The interviews took place from late 2010 until the spring 2012. Our fieldwork in the Mikkeli area took place between $8^{\text {th }}$ and $12^{\text {th }}$ of August 2011.

Our interviews normally lasted approximately one hour. Informants where typically located through key persons, such as employers, foremen, shop stewards and officials. However, we also contacted some participants (especially cleaners) spontaneously, when they were seen at the work place. Key persons, who granted access to the field, were also interviewed. Most of the seasonal workers were Russian (23), and we have used simultaneous interpretation in the interview situation as well as Russian language speakers to transcribe the audio recordings and translate them from Russian into Finnish language transcriptions. Four Estonians and one Ukrainian are included in the sample of seasonal workers. Typically the researcher asked questions in Finnish, which our interpreter then translated into Russian. The informant answered in Russian and finally the interpreter translated the response into Finnish. Among the bus drivers most were Estonian, and typically the interviews were conducted in Finnish. In some cases, when the informant had only resided for a short time in Finland, or was a Russian speaker from Estonia, Russian interpretation was utilised. In some cases simultaneous interpretation to and from Estonian took place.

Among the agricultural workers, our informants worked in several different companies (farms) and had stayed in Finland for various periods of time. The temporariness of the stay and work consequently vary amongst the informants. In our understanding temporariness means a residence in Finland with an obligation to leave the country after a certain period, or the possibility of leaving the country at some point in the future to return to one's home country or another host country.

The agricultural workers interviewed represent the most typical case of temporariness, as they stay during the harvesting period in Finland and return to their country of origin after the season has ended. But, they often return the next year and many have visited Finland several times to picking berries or harvest vegetables. Many work with so called berry-picking or tourist visas, which place strict restriction on the period of time they are allowed to work in the country and place formal conditions such as levels of taxation, insurance, et cetera. Our informants vary considerably only when it comes to country or area of origin. Most of the agricul- 
tural workers come from Russia. Most bus drivers and construction workers come from Estonia, and many cleaners come from developing countries, such as Bangladesh, Ethiopia and Nigeria. The ages of the informants vary between 20 and 60 years, of which seasonal workers were predominantly young female students and bus-drivers were middle aged men. Many informants moved to Finland as students and started working whilst at the same time continuing their studies.

The interviews are analysed as individual cases and presented as such. They are illustrative for a variety of circumstances. Occasionally, where necessary, we draw upon interview excerpts in order to provide illustrative examples from our corpus of data.

\section{DO TEMPORARY MIGRANTS WANT TO KNOW THEIR RIGHTS?}

\section{Here and there - temporality and working life}

When you come here [to Finland], you must understand that you are on your own and that you should work hard and then rest when you are back to [sic] Russia. (Marya, female agricultural worker)

Amongst the agricultural workers, there was a sharp distinction between their working lives and their 'normal' lives they had left behind in Russia. Life is organized according to seasonal work, between working in Finland and family life at home. As such, Finland is understood as a temporal and geographic space in which one works for a season, but does not remain. Strategic plans are made to save as much as possible in order to return to Russia with enough money to survive the winter months in the migrants' local communities. In the above excerpt, Marya distinguishes between a present working time that involves hard labour and a future period of rest upon returning to Russia. For Marya the opportunity to work for a season in Finland allows her the opportunity to save money to support her daughter whom she had left in the care of a sanatorium whilst working abroad. Working abroad substitutes the need for social political measures (i.e. unemployment support) in her home country, and due to her current existence consisting solely of work, social political (i.e. childcare and child benefits) measures are not needed in the host country either.

Similarly, a second Russian agricultural worker makes the distinction between working and living in the excerpt below.

I don't live in Finland. I only work here. I have been working for [Employer's name removed] and doing sea- sonal jobs for a few years. I usually work for three months, doing berry picking. (Vera, female agricultural worker)

Here, the migrant worker reflects that she has been a circular migrant for a number of years. Work is again seasonal and she reflects that her migration to Finland is based on the availability of berries to pick, for which she is paid by the kilo. Her biography has been marked by seasonal periods of work, which are limited by limitations placed upon her both by the seasons themselves and visa restrictions. However, in respect to her future plans, Vera notes that she now has a one-year visa, and that the farmer has promised work during the winter season also. She expresses a desire to make Finland her home, but notes that she needs to reside in the country for four to five consecutive years in order to gain permanent residency. This future time orientation distinguishes between the uncertainty of present and past working life in Russia and present and future comfort of a peaceful life and a better salary in Finland. Finland is conceptualized a utopia free from the troubles that she has experienced in Russia (i.e., crime). Reflecting upon the regular migrations she has made in the past Vera states that she considers Finland "a second home. I cannot live without Finland anymore!" In the latter part of this passage Vera reveals how her present and her self-identity are intrinsically tied to the time she spends working in Finland. But even some of the informants who have a regular job, a permanent residence permit and have stayed in Finland for several years still seem to perceive their stay as temporary and only involving work.

Ilmar, a construction worker from Estonia, draws in common with the accounts of agricultural workers a distinction between coming to Finland to live and coming to Finland to work.

It's one thing to come here [to Finland] to work and another to come here to live. (IImar, male construction worker)

Much like the above accounts, Ilmar distinguishes between a stable present (and future) and the ambiguity and instability of his past in Estonia. The certainty of the future is perceived as an important motivator to come to Finland to work. - "Knowing you will have a job tomorrow". Knowing that you will be welcomed back for the next season gives a sense of security. A sense of coherence is indeed an important aspect for people living in temporary settings. For IImar, Finland represents a dynamic, forward thinking place in which "people think about their future". He continues by stating "all the people think [sic] about their future... also the government. Here [in Finland] 
everyone builds the future." Through a future time orientation IImar articulates his stable present, his contentment in his work and his settled life as a permanent resident.

Throughout his interview Ilmar repeatedly draws upon metaphors of "building the country" to explain his working life and his presence in Finland. His biographical conceptualizations of time develop a narrative in which past experiences and present working life contribute to a collective national project that extends into an imagined future. Despite being settled, IImar states a desire to return to Estonia to be with his wife and son who chose not to join him in Finland. However, he notes that he has grown accustomed to the "good conditions" (a good material situation and the certainty of state support if he were to lose his job) in Finland, which would make it difficult to return to Estonia.

In the current study it also seems common that circular migrants focus mainly upon present issues such as earning money in order to be able to live in the home country. The past is almost entirely neglected and one berry-picker mentions that she prefers not to talk about the home country, yet she would return there if she fell ill. Thus there seems to be a big emphasis on the present whereas the past and the future do not really matter in the current state of time.

- "I am not interested in Russian media. The less I know about Russia, the better. I want to live in peace."

- $\quad$ "At that moment it was most important to earn money in order to help my family" 5

Many temporary workers arrive for a limited period of time in order to work. They arrive with the intention to earn as much money as possible to bring back home to support them and their family there. While in Finland, they find the living comfortable, although almost entirely directed towards working. Some temporary workers do not want to think about their home countries and wish to stay permanently. They find it, however, problematic to fulfil the formal requirements, and are consequently more directed towards the present than to making any future plans.

\section{Lacking social citizenship due to problems with per- mits and contracts}

Many migrants face uncertain situations in relation to gaining residence and work permits. Previous research in Finland (Himanen and Könönen, 2010; Könönen and Himanen, 2011; Könönen, 2012) has shown how people become dependent of their employer in cases where the prolongation of the residence permit is dependent on an existing work contract. And, different residence statuses entitle to different possibilities to work and social benefits. The different statuses depend in their turn in a high degree on the temporal aspects of migrants' stay in the country.

Our informant Rifat demonstrates how difficulties with residence permits places him in a prolonged intermediate stage, where all future plans are made difficult and the future is regarded with anxiety. Rifat lost his right to study because of new language skill requirements. As a consequence the police rejected his application for residence permit. Rifat then needed a work permit in order to stay, and he got a full time job. The police told him that he would have to cancel his study place in order to get a work permit, which he did, and got a paper from his school indicating that he'd withdrawn from his studies. The police then, however, refused to give the work permit and asked him to stop working. Their decision was based upon the argument that he was a student who came to Finland to study. They stated that no work permit would be given until he completed his studies. Rifat then contacted a lawyer and they made an appeal against the decision. After six or seven months a decision was made and the police were asked to give Rifat a permit so that he would also get working visa. The police, however, still did not give him his visa, but asked him to wait for them to contact him. Rifat waited for a further two months following which his lawyer had to send an email to the police in order to get them to react. Still, after four months Rifat had not received his visa.

It also seems as though the informants living in a temporary setting are motivated to look for information when it directly influences their possibility to stay in Finland or has a directly positive influence on their standard of living such as receiving KELA benefits. The most frequent issue among our interviews regarding problems with social insurance was the lack of the national KELA insurance, due to a short-term work contract, and consequently a lacking possibility to register as a resident in the country. Another frequent problem is the student residence status, which does not entitle to the KELA card. Somadina, another informant, has now received a KELA social security card, as he is married. Before he married, he did not have a KELA card, as he was 'just' a student. Amongst the temporary agricultural workers interviewed in this study, the informants regularly referred to their informal networks of friends 
and acquaintances - both in Finland and in their country of origin - through whom they gained information on employment opportunities and whom they relied upon for social support. Their residence status does not entitle them to any kind of social security within the formal system whatsoever. Their precarious situation in which they were reliant upon short-term working contracts that could be ended without notice brought to the fore the local and transnational networks these workers develop and rely upon for support in instances where they are not entitled to unemployment benefits upon becoming unemployed.

Nadia (Russian agricultural worker) was working in Finland on a farm as a berry picker for the first time. An intermediary, a company that organizes working trips abroad for Russians, had promised her work for three months. However, when she arrived in Finland to begin work she discovered that there would be work for two weeks and not three months as promised. When confronted with this problem she contacted the intermediary and was told that it wasn't their problem as they were only responsible for arranging one work placement. After speaking with a fellow Russian woman who was working with her group, she found another employer that offered jobs to temporary seasonal workers. Through their local Russian contact, Nadia and her fellow employees found two further seasonal jobs picking berries and harvesting crops, which allowed them to remain in Finland for the full period during which her visa was valid. Nadia notes that after paying the intermediary Nadia will not have made any extra money whilst working in Finland. Rather, she will take away an experience.

The intermediary company arranging her employment in Finland made Nadia false promises. It was only through networks of fellow Russian migrant workers that she was able to find work to support her during her stay. A similar reliance upon fellow Russian migrant workers and associations in Russia (i.e. the Ingrian Association) was reflected in the narratives of other circular migrants involved in the harvesting of vegetables and the picking of berries in and around the Mikkeli area. Employers were described as holding all of the power: in some instances workers were denied breaks and an employer remarked that there were plenty more migrants looking for work, implying that the workers were easily replaced as a cheap source of manual labour.

Here, time features as short periods during which employment was offered and retracted based upon the needs of the farmer. Spatial movements between employers and farms divide short periods of work. Local and transnational contacts are sought out in order to provide support in precarious circumstances and forced movements and searches for employers interrupt the rhythm of seasonal work. The agricultural workers narrate their experiences referring to recent past events and their present circumstances. The above example shows that the expected temporal organization of the worker's seasonal migration is interrupted by fuzzy work contracts, broken promises and immediate concerns for one's welfare.

\section{Future plans dependent on work}

From our interviews it is evident that the future plans and strategies of migrants are mainly dependent on their work situation. This is clearly in line with Yijälä, Likki, Stein, and Jasinkaja-Lahti's (2009) findings about the employment relation having an impact on the motivation to establish an attachment to Finland. This is not surprising considering that they have in most cases arrived in order to work. Our departure, however, emerges from questions raised about working contracts and nature of the work itself, as well as the situation of the individual migrant regarding his or her various permits. Those who come for fixed term seasonal work in the agricultural sector are, for instance, clearly directed towards staying temporarily in the country, and do not become integrated to any degree in the Finnish social welfare system. Sometimes migration becomes circular with seasonal work in Finland reoccurring year after year. A desire to migrate to Finland more permanently is sometimes raised, but not elaborated upon - the future remains somewhat ambiguous as the present concerns with earning a wage are pronounced. When asked by the interviewer about her future dreams and ambitions, Tania responds that she does not have any dreams; yet following a short pause, she declares "I want to get married with a Finn." Whilst her subsequent laughter indicates that she was not entirely serious when making this statement, it does, however, expose an assumption that marriage to a Finn is a viable route to residency in Finland. Indeed, one of our Russian interviewees did just this, having married the proprietor of the farm that she had previously visited as a seasonal worker.

Those who come for studies have often had the same approach but it has gradually changed into a view where staying is an option if one is able to find satisfactory employment. However, if the work situation is problematic then students expect to return home or further to another country after completing their 
studies. Yonas, for instance, is a student who works in a cleaning company and has been in Finland for three years. He explains that if he cannot find work within his profession and which corresponds to his education, he will immediately return to Ethiopia. Francis, who arrived approximately two years before Yonas, in order to study and who has got two degrees, does not want to stay in Finland. He is currently cleaning and he has not found work in a field that corresponds to his education. (This is also valid for Somadina from Nigeria who expected to get a job corresponding to his degree.) Francis has also faced discrimination in job applications. He wants to return to Cameroon, but finds it difficult to start all over again from the beginning. He regrets the moment he decided to start migrate, and is frustrated in the present and pessimistic about his future.

Many temporary migrants' experiences of and interest in the social security system is basically filtered through questions about work permits and job experiences. They have, however, as students been covered by health care and social security provided by the educational institution. The issue about Finnish social security emerges gradually, when the link to the educational institution becomes less dominating and with the prospect of changing the visa from a student visa to a workers visa. Currently a strategic situation where the interests of the migrant and the state differ is when the foreign student is graduated and considers staying in Finland. During her/his studies, (s) he has worked part time, but has not been entitled to the welfare provisions and social insurance. When graduating (s)he is considering staying in the country and expects to work with a job that corresponds to his/her degree. (S)he expects also to become entitled to the full social citizenship. This is where the interest of the state becomes ambiguous. On the one hand the utilisation of the skills that the foreign student has acquired in Finland through free education would be beneficial to the country. On the other hand the costs involved with providing him/her with social security are not desired. This is particularly problematic if there are problems with employment (due to for instance racism and discrimination) or the person wants to bring his/her family also to the country (cf. Koski 2011). In this case there is the temptation for the state to keep the migrant outside of the social security system and to thus exploit them with draining them of their work input, but not providing anything in return.

Some people who have arrived as students would like to stay, mainly due to family reasons and social networks. But, even in these cases the employment situation has an impact on the prospect of staying. Even as Somadina is married he does not want to stay because he does not have a job that corresponds to his level of education. Rifat would like to receive KELA support, but his possibility to stay and receive support from KELA is dependent upon his status being formally upgraded (in terms of his visa and residence permit) from student to worker. ${ }^{6}$ Thus, he is dependent on work in order to stay, even though his primary motivations of staying are not work related. Nonetheless, work plays a crucial role in the future orientation and strategic choices of temporary migrants.

\section{Lacking knowledge of social security and social insurance}

Partially the awareness about the social security of Finland is dependent on the country of origin of the migrant, and its social system. This explanation for lacking knowledge refers to a cultural and post-colonial perspective, whereby the social structure of many sending countries is such that the complex social insurance of receiving countries is incomprehensible for the migrant. In many societies long term planning for the future is difficult due to a lack of comprehensive insurance and pensions savings. But the lacking awareness is not surprising in a global perspective. After all Nordic societies constitute an exception in the world in terms of their extensive welfare system. This results in an orientation to the present and perhaps even fatalism - "What will be will be". Partially this awareness, or rather lacking awareness, is also dependent on the migrant's age: single, middle-aged migrants are normally not as aware or interested in social security issues as older migrants or people with families.

A lack of awareness among these groups has also life situational reasons. Usually those migrants who arrive in order to work are more healthy than the average, and are thus not in need of welfare services. Finding out about social security consequently becomes a more abstract question, which is not introduced by practical issues in life. Thus it is frequent that migrants do not know about the social security system of Finland and have no clue about what kind of welfare provisions they are entitled to.

Francis, who comes from Cameroon, has resided in Finland for five years. He does not know what social security means, and it needs to be specified by the interviewer. When speaking about social security he emphasises safety; Finland is "a very safe country". Rifat (Bangladeshi), who has resided in Finland for three years, says at the beginning of his interview that 
he does not know much about the social system in Finland. He possesses in a quite typical fashion some rudimentary information about the workers compensation insurance, and that the boss has an insurance policy for him but he does not know what kind of insurance it is. Rifat thinks mainly about the health insurance, as he has had pain in his leg and they paid him a salary whilst he was on sick leave. Until now he has been preoccupied with getting a permit in the first place and being allowed to stay, and he has therefore not been able to find out about his social security issues. He does not have the possibility to make any long-term strategies concerning his future until his problems with permits have been solved. Another Bangladeshi man, who has also resided in Finland three years, is relatively aware about his social security. He knows that he has a private insurance, he knows about the trade union and is a member, and he knows about the pension. His knowledge comes from the student tutor who informed him about the social security. He is, however, not sure about his health insurance and the reimbursement or pay during sickness leave, but he has a clue about it. He does not save up to take holidays and he is not aware about if he is off as holidays or just on his own. Neither does he know the minimum wage in his occupation.

In the above cases lacking knowledge about the social security is perhaps explainable with the age, gender and the country of origin of the informants. These informants have stayed for several years, and still do not know much about the system of social security. Amongst the migrant agricultural workers interviewed, many possessed little to no knowledge of their social security coverage and of social insurance related issues. In their case it is understandable in relation to the short period of stay they are in the country. In some instances employees were aware that they were making employment related pensions contributions, but there was little knowledge about these deductions or the possibility of receiving a pension upon retirement. In the excerpt below, Maria indicates that she is aware that her employer is collecting pension contributions from her salary.

Yes, there is a certain percentage. The employer pays us the salary through a firm. We are working here via this firm. This firm then deducts the pension and other payments from our salaries. (Maria, Russian agricultural worker)

Elsewhere in the interview, however, Maria indicates that she does not think that she is entitled to receive a pension from Finland unless she resides in the country, which is not valid information. Each employed person has the right to have their pensions saving from Finland once when they retire. As persons on short stay visas between 90 and 180 days, it is conceivable that such circular migrant agricultural workers do not consider it important to inform themselves of such long-term social security benefits when their stay in Finland is short and opportunities to settle remain somewhat elusive. Accordingly, the conditions of temporariness that seasonal agricultural work entails does not encourage such workers to invest their time in learning the complex system which entails long-term rewards.

By contrast when discussing the short-term benefits like holiday pay that is included within the entitlements of all employees, many informants have some awareness of their entitlement to remuneration, but they were unaware of the specific details. In most instances the agricultural workers were confident that they received/were entitled to receive some compensation. Often the informants stated that they were aware of their holiday entitlement. For instance, when Tania was aware that she was entitled to holiday pay, she responded: "Yes, there is a certain percentage that we get in winter." In contrast to the long-term investments, there is a short-term benefit from such working related benefits. In fact, whilst the migrant does not benefit from other social insurances attached to residency or long-term payments into a fund, he or she is entitled to holiday pay as an employee. This is a right, which is not attached to permanent residence and social citizenship.

In Finland it is unusual to buy a private health or pensions insurance. Among migrants this, however, is not the case. It is common among students to purchase private insurance, as they are not covered by the KELA public insurance. Additionally students are obliged to have deposits of 6,000 Euros in their bank account when commencing their studies in Finland. This is also a kind of private insurance that the state requires from foreign students. Amongst agricultural workers visiting Finland on temporary tourist working visas, those interviewed all claimed to have purchased private insurance in Russia prior to travelling to Finland. This is because, as they note, it is mandatory for all migrant workers to purchase insurance. Indeed, several interviewees intimate that without insurance one cannot come to work in Finland. Some state that it is a prerequisite for acquiring a visa. For the most part, the respondents had little to no confidence in the private insurance policies they had purchased, expressing a doubt that they would receive the coverage that they had paid for. 


\section{Experience related knowledge about social insurance}

Practices vary between farms and work places in terms of work initiation, where all different issues would be dealt with such as insurances, pensions savings, holiday pay and holiday bonuses. Consequently those who come first time are often not enlightened about the different arrangements, and the level of taxation in Finland is also often a negative surprise. When seasonal workers arrive repeatedly they also learn gradually through experience how things work. In seasonal work one crucial part of the future orientation is to gather experiences. This is a future orientation that manifestly builds upon past experience. It involves taking a risk when going into migration and employment without knowing about the conditions and rules that apply. In terms of temporality this approach leads to biographical time conceptions about "when I was there, these things happened". But despite the experience accumulating way of finding out about social security and working conditions, there are great degrees of contingency in the securing of the future among seasonal workers. Their income is dependent on the harvest (amount of berries to pick) and consequently the possibility of earning a sufficient amount to cover travel costs, living costs and to save for the winter season is dependent on the cycles of nature and local climate conditions. Agricultural work appears to tempt fatalism, as the amount of work and income are independent of individual acts and intentions, and it is directly opposed to the strong agency of the migrant who strives to take her destiny into her own hands. Indeed, several of our informants reported that the intermediaries through whom they acquired the positions had taken advantage of them. The monies they had paid out for their services and the high levels of taxation imposed upon them resulted in the unfortunate circumstance that they were unable to earn a sufficient amount to return home with any savings. As such these individuals were positioned as helpless actors slaving away to profit others.

Despite the earnings-related pensions insurance being accumulated from the beginning of a new employment, many other social benefits are not available to migrants who stay in the country on a temporary basis. Sometimes there is a cost involved with trying to get the benefits and social services one is entitled to. The system encourages the migrant to take care of himself. In Rifat's court case it was considered positive that he did not utilize income support while he did not study and had to stop working. Somadina was sick and went to the hospital, as he was told to do and he thinks that he was sacked because of this and the fact that he went to Nigeria on vacation.

Even earnings-related pensions are often not subjectively relevant for the migrant worker, as the work contract is short term and the subjective motivation of doing the work is predominantly earning money for living costs and family. Migrant workers are further often of low average age, which means that they do not consider issues related to old age and retirement yet. This is a common feature also among native workers in their younger years, but particularly prevalent among migrants, due to the fact that pensions systems become less obvious and clear when changing country. Most other social benefits are residence based. It is the Finnish Municipalities and The Social Insurance Institute of Finland (KELA) who administer these benefits to those who have the appropriate citizenship or residence status. Frequently the experiences of having to do with these authorities are negative due to bureaucracy.

Tom is frustrated and disappointed with KELA, The Social Insurance Institute of Finland, which had a long waiting time before assistance was approved when he got the responsibility of his children after separating with his Finnish wife. He uses expressions like the civil servants at KELA not being service minded and working for the people, and that "how did they suppose he was to get along while waiting three weeks for the decision".

Temporary migrants are excluded from the population who have access to these benefits, due to the fact that they are not entitled to the KELA insurance card or are not accepted as residents of a municipality. As seen in the previous section, the temporary migrant habitus (Bourdieu, 2000) adjusts subjective expectations to objective conditions and decreases the motivation of immigrants to find out about their social security while in the country. This is further enhanced due to individual insurance policies being demanded by the state in order to enter the country in many cases (i.e. amongst agricultural workers and students). This simultaneously inspires migrants to maintain transnational connections, as the host country does not provide social security coverage.

It was common for the agricultural workers to state that they would return to Russia to seek medical assistance if they were taken ill. In some instances the employer (the farm owner) provided over the counter medications to the employees when they needed assistance, but in others the respondent indicated that they had returned to Russia to seek treatment. This was the case for a female agricultural worker who 
chose to return to her hometown of Petrozavodsk in order to visit a dentist as she was suffering toothache towards the end of her working contract on the farm. Only one of the agricultural workers interviewed indicated that they had sought medical help whilst employed in Finland. Maria, a regular seasonal worker who has worked in Finland for five years, noted that once she had had a toothache and that it was her employer who had taken her to the dentist in the nearby town of Mikkeli. She even notes, rather admiringly, that it was her employer who paid for her treatment. The migrant workers were largely unaware as to whether or not their employers had purchased insurance covering their working time activities and they speculated that if they had an accident whilst at work they would endeavour to return to their home country in order to seek treatment in such instances also.

In many cases the lack of KELA insurance resulted in the necessity to use private medical care, which is an expensive option. But among bus drivers a widespread knowledge existed about the occupational health care and the different provisions of the public health insurance.

Among temporary migrants the welfare system is not valued particularly highly and the motivation to contribute to the system is quite low. The rationale for this attitude is, however, different among these lower ranks, as they cannot access such benefits without permanent residency. They contribute to the system through taxes, as in the case of agricultural workers (i.e. berry-pickers) who pay $35 \%$ tax on source on income surpassing the 510 euros lower limit, but cannot get anything in return and will soon leave the country. Consequently their motivation to contribute to the welfare system is limited. Commonly they complained of shouldering a high tax burden with little reward for their labour. As a result, there is often a greater temptation not to follow the valid legislation about working hours and wages, and to not pay taxes as the benefits of the system are out of reach for these individuals.

\section{CONCLUSIONS}

The emergent paradoxes and contradictions of residence based social security and the tax burden placed upon seasonal migrant labour, without the obligation to provide welfare services, suggest an unequal ordering of persons according to their citizenship and residence status. As such, the use of seasonal work and temporary, short-term visas can be interpreted as a return to guest-worker (Gastarbeiter) policies in order to minimize labour costs when currency devaluations are no longer possible (cf. Katzenstein, 1985). These were, however, not previously applied in Finland. They provide a buffering labour force, which is a means of dealing with economic cycles. A ready source of labour from the economically disadvantaged countryside, towns and cities of western Russian Federation and Estonia is drawn upon to supply manual labour at a relatively low cost.

The motivation to become covered by social insurance appears to be directly related to the occupation and employment sector of the temporary migrant worker, as different sectors have different relations to time and temporality. In agricultural work the time perspective is seasonal and cyclical, which decreases the motivation to consider social security as valid during the particular period of work, but when the work is repeated the next harvesting time, a continuity emerges which perhaps also increases awareness of life cyclical issues. In blue-collar work the daily routine and regularly physical burdens with negative health consequences, increase the awareness of social insurance issues. Employers are steered by the time perspective of the sector, where seasonality is characteristic of agricultural work, which increases temporality. However, in some instances exchangeability of people is diminished by the cultural ethos of the rural countryside. In cleaning the turnover rate of workers is high and the skill level is low, which increases the short-term perspective of the employers (cf. Rasmussen and Håpnes, 2012, p. 18). Gender seems to be one of the most important conditions in social security issues, where male workers are least aware and attentive to such issues.

Among immigrants, especially third country nationals who rely upon residence and work permits, a securing of ones future is not an option in the same sense it may be for the majority or for EU citizens. Because of short time perspectives, and dependence on momentous time occurrences (permit or not), future time orientations become difficult. For those who work with seasonal work (i.e. in the agricultural sector) issues regarding their working conditions become clear through practical experience.

This article has shown how motivations to find out about the welfare system are linked to the length of stay of the migrant, sector of work, gender of the temporary worker, country of origin of the worker. Finally motivations are in a high degree influenced by objective conditions of accessing the welfare benefits of the country, for instance conditions related to problems in 
receiving work permits, residence permits, and KELA insurance cards. The article shows how many temporary workers, especially within seasonal work, are in Finland solely in order to work, and are not directed towards other aspects of life while in the country. Temporary migrants learn about the Finnish Social Security System through their own experience, which makes their knowledge dependent on initiation processes at work places. In many cases a private insurance is required from the temporary worker in order to get the visa and many immigrants are not motivat- ed to contribute to a system, which they don't benefit of, and they illustrate a conditional solidarity towards other immigrants depending on whether they work and contribute to the system or not (cf. Forsander, 2002). The possibilities provided by the social system are incorporated by migrants, who reflexively adjust their subjective expectations to their objective conditions (Bourdieu, 2000). Sometimes this adjustment is done in frustration as benefits are out of reach for the migrant, despite having to contribute to the system financially by paying taxes.

\section{NOTES}

[1] In this case remittances and the diffusion of new ideas and innovations is often presented as positive consequences. On the negative side the drain of skilled, educated workforce to wealthier countries is a real threat for the sending countries, which creates labour shortages and the deprivation of professionalism in the sending country.

[2] The situation is different for migrants who have immigrated due to marriage or family reasons or who have received permanent asylum and have refugee status.

\section{REFERENCES}

Bakker, R. M. and Janowicz-Panjaitan, M. K. (2009). Time matters: The impact of temporariness on the functioning and performance of organizations. In Kenis, P. N., Janowicz-Panjaitan, M. K. and Cambré, B. (eds.). Temporary organizations: Prevalence, logic and effectiveness. Cheltenham: Edward Elgar Publishing, pp. 121-141. http://dx.doi. org/10.4337/9781849802154.00013

Bergmann, W. (1992). The Problem of Time in Sociology. An overview of the literature on the state of theory and research on the 'Sociology of Time', 1900-82. Time \& Society, 1, 1, pp. 81-134. http://dx.doi. org/10.1177/0961463X92001001007

Bourdieu, P. (2000). Pascalian meditations. Cambridge: Polity Press.

Boyd, M. (1989) 'Family and Personal Networks in International Migration'. International Migration Review, 23, 3, pp. 638-670. http://dx.doi. org/10.2307/2546433
[3] The parallel between temporary migration and guest worker policies is illustrated by the fact that there is a lack of national policies relating to circular migration in Europe, but countries that used to apply guest worker schemes (Austria, Germany and Netherlands) are with the aid of these experiences exploring possibilities to manage, control and facilitate circular migration. Austria has for instance expressed "concerns [--] that migrants would not return, once their work season was complete, and that they thus would require integration measures and provisions" (European Migration Network, 2011: 32).

Brochmann, G. and Hagelund, A. (2010). Velferdens Grenser. Innvandringspolitik og velferdsstat i Skandinavia 19452010. Oslo: Universitetsforlaget.

European Migration Network (2011). Temporary and Circular Migration: empirical evidence, current policy practice and future options in EU Member States. Luxembourg: Publications Office of the European Union.

Esping Andersen, G. (1990a). The Three Political Economies of the Welfare State. International Journal of Sociology, 20, 3, pp. 92-123.

Esping Andersen, G. (1990b). The three worlds of welfare capitalism. New Jersey: Princeton University Press.

Facta 2005. Suomenkielinen tietosanakirja [CD]. Helsinki: WSOY.

Fortier, A. M. (2012). The Migration Imaginary and the Politics of Personhood. In Messer, M., Schroeder, R. and Wodak, R.
[4] Increasing the minimum age for receiving the old age pension and lengthening work carriers are other measures introduced in the debate, which concern the entire population and are thus politically highly controversial.

[5] "Sillä hetkellä oli tärkeintä tienata rahaa, jotta voin auttaa perhettä".

[6] This is valid in cases where people with $\mathrm{F}$ of $\mathrm{B} 2$ and $\mathrm{B} 3$ status want to upgrade the status into $B 1$ or $A 2$ status - source for statuses: http://www.finlex.fi/data/ sdliite/liite/2759.pdf). 
Helander M. and Saksela-Bergholm, S. (2012). Ulkomaalaisten kausityöntekijöiden kokemukset maataloustyöstä, Maaseudun uusi aika, 3, pp. 29-36.

Hersch, E. L. (2011). Temporality and motivation: A phenomenological approach to psychotherapy. Existential Analysis, 22, 1, pp. 96-106.

Von Hertzen-Oosi, N., Harju H., Haake, N. and Aro, T. (2009). Ulkomaalaisten tilapäinen työnteko Suomessa, Työ- ja elinkeinoministeriön julkaisuja, Työ ja yrittäjyys, 37.

Himanen, M. and Könönen, J. (2010). Pako ja pakko - turvapaikanhakijoiden kokemuksia prekaarista työstä. In Wrede, S. and Nordberg, C. (eds.) Vieraita työssä. Työelämän etnistyvä eriarvoisuus. Helsinki: Gaudeamus Helsinki University Press, pp. 45-71.

Hirvonen, M. (2011). Ulkomaista työvoimaa koskevan sääntelyn toimivuus. Harmaa Hirvi Oy 27.12.2011. [On line] [Search date: 30.8.2013]. Available from: http://www.poliisi.fi/intermin/ biblio.nsf/918B04C7A3631B65C225 7A0E002ED78F/\$file/Arvio\%20ulkomaiseen\%20ty\%C3\%B6voimaan $\% 20$ I i i t t y v \% C $3 \%$ A 4 n \% 20 s\%C3\%A4\%C3\%A4ntelyn\%20toimivuudesta\%202011.pdf.

Jønsson, H. V. and Petersen, K. (2010) Danmark: Den nationale velfærdsstat møder verden. In G. Brochmann, G. and Hagelund, A. (eds.) Velferdens grenser. Innvandringspolitikk og velferdsstat i skandinavia 1945-2010. Oslo: Universitetsforlaget, pp. 131-210.

Katzenstein, P. J. (1985). Small States in World Markets: Industrial Policy in Europe. Ithica: Cornell University Press.

Korkman, S. (2012). Talous ja utopia. Jyväskylä: Docendo.

Koski, O. (2011). Maahanmuutto ja hyvinvointivaltion rahoitus. In Helander, $\mathrm{M}$. (ed.) Totta toinen puoli? Työperäisen maahanmuuton todelliset ja kuvitellut kipupisteet. Helsinki: SSKH Skrifter 31, pp. 14-23.

Könönen, J. (2012). Prekaari työvoima ja työn uudet hierarkiat metropolissa. UIkomaalaiset matalapalkkaisilla palvelualoilla. Sosiologia 2, 3, pp. 190-205.

Könönen, J. and Himanen, M. (2011). Prekaarisuuden tuotanto - Turvapaikanhakijoiden kokemuksia työstä. In Helander, M. (ed.) Totta toinen puoli?
Työperäisen maahanmuuton todelliset ja kuvitellut kipupisteet. Helsinki: SSKH Skrifter 31, pp. 111-118.

Miles, M. B. (1964). Innovation in education. New York: Columbia University.

Piper, N. (2010). Temporary economic migration and rights activism: an organizational perspective. Ethnic and Racial Studies, 33, 1, pp. 108-125. http://dx.doi. org/10.1080/01419870903023884

Sennett, R. (1998). The Corrosion of Character. The Personal Consequences of Work in the New Capitalism. New York: Norton.

Rasmussen, B. and Håpnes, T. (2012). Permanent Temporariness? Changes in Social Contracts in Knowledge Work. Nordic Journal of Working Life Studies, 2, 1, pp. 5-22. http://dx.doi.org/10.19154/ njwls.v2i1.2349

Tartakovsky, E. and Schwartz, S. H (2001). Motivation for emigration, values, wellbeing and identification among young Russian Jews. International Journal of Psychology, 36, 2, pp. 88- 99. http://dx.doi. org/10.1080/00207590042000100

Ward, C., Bochner, S. and Furnham, A. (2001). The psychology of culture Shock. Routledge: Hove.

White, A. and Ryan, L. (2008). Polish 'Temporary' Migration: The Formation and Significance of Social Networks. Europe-Asia studies, 60, 9, pp. 1467-1502. http://dx.doi. org/10.1080/09668130802362227

Yijälä, A., Likki, T., Stein, D. and JasinkajaLahti, I. (2009). The adjustment of highly skilled international professionals in Helsinki. In Jasinkaja-Lahti, I. and Laine, M. (eds.) Founding the European Chemicals Agency: The perspectives of the employees and the authorities of the City of Helsinki. Helsinki: City of Helsinki Urban Facts, pp. 19-163.

\section{Web resources}

Hyvinvointikatsaus 4/2012. [On line]. Available from: http://www.stat.fi/artikkelit/2012/art_2012-12-10_002.html?s=2

Julkunen, R. Hyvinvointivaltion suunnanmuutos. Ennen ja nyt. Historian tietosanomat. Turku: Turun yliopisto. [On line]. [Search date: 30.8.2013]. Available from: www.ennenjanyt.net/4-01/ julkunen.htm
KELA, (2010). Kela - The Social Insurance Institution of Finland. [On line]. [Search date: 27.8.2013]. Available from: http://www.kela.fi/in/internet/liite. nsf/NET/250808095953HS/\$File/Kela yleisesite_eng_net.pdf?openElement

Laws and Statutes of Finland (www. finlex.fi): Act on the Application of Residence-Based Social Security Legislation 30.12.1993/1573 Kotikuntalaki 11.3.1994/201

STM. Characteristics of the Social Security System in Finland 2007:9. [On line]. Available from: http://www.stm.fi/c/ document_library/get_file?folderld=39 503\&name=DLFE-6714.pdf

The Finnish Immigration Service (2013). Working in Finland. [On line] [Search date: 30.8.2013]. Available from: www. migri.fi/working_in_finland.

The Finnish Tax Authority. Veronumerorekisteriin on merkitty 562289 henkilöä. Verohallinnon tiedote. Press announcement by the Finnish Tax Authority, 20.8.2013. [On line] [Search date: 30.8.2013]. Available from: www.vero. fi/fi-Fl/Tietoa Verohallinnosta/Tiedotteet/Uutisia/Veronumerorekisteriin_ on_merkitty_562_28(21960).

The Ministry of the Interior (2011). Maahanmuuton vuosikatsaus 2011, Helsinki: The Ministry of the Interior. [On line]. [Search date: 30.8.2013]. Available from: http://www.migri.fi/download/14582 Maahanmuuton vuosikatsaus_2010_fi.pdf?e679feb3686cd088

The Ministry of the Interior (2012). Maahanmuuton vuosikatsaus 2011, Helsinki: The Ministry of the Interior. [On line]. [Search date: 30.8.2013]. Available from: http://www.migri.fi/download/34214_maahanmuutto_2011_tilastokatsaus.pdf?d65cf1b3686cd088.

The Ministry of the Interior (2013). Maahanmuuton vuosikatsaus 2012, Helsinki: The Ministry of the Interior. [On line]. [Search date: 30.8.2013]. Available from: www.migrifi/ download/4311_43667 Maahanmuuton_tilastokatsaus2012_web. pdf?38b2e4b3686cd088.

YLE (2013). Kevät toi verorekisteriin muurarin - viikossa jopa 5000 uutta rekisteröityä. YLE uutiset, talous 22.5.2013. [On line]. [Search date: 30.8.2013]. Available from: yle.fi/uutiset/kevat_toi_verorekisteriin_muurarin_viikossa_jopa_5_000 uutta_rekisteroitya/6652726. 